\title{
Differential Hepatic Gene Expression and Antioxidant Activity in Male and Female Rats Induced by Subchronic Aflatoxicosis B1
}

\author{
Ghada Ali Omran ${ }^{1 *}$; Nagwa Thabet Abo El-Maali ${ }^{2}$; Mady Ahmed Ismail ${ }^{3}$; Nashwa Ahmed \\ Mohamad Mostafa ${ }^{4}$; Nasser Masood Nasser ${ }^{5}$
}

\begin{tabular}{|c|c|}
\hline & ABSTRACT \\
\hline $\begin{array}{l}\text { KEYWORDS } \\
\text { Genotoxicity; } \\
\text { Aflatoxin B1; } \\
\text { Hepatic; } \\
\text { Rats' gender. }\end{array}$ & 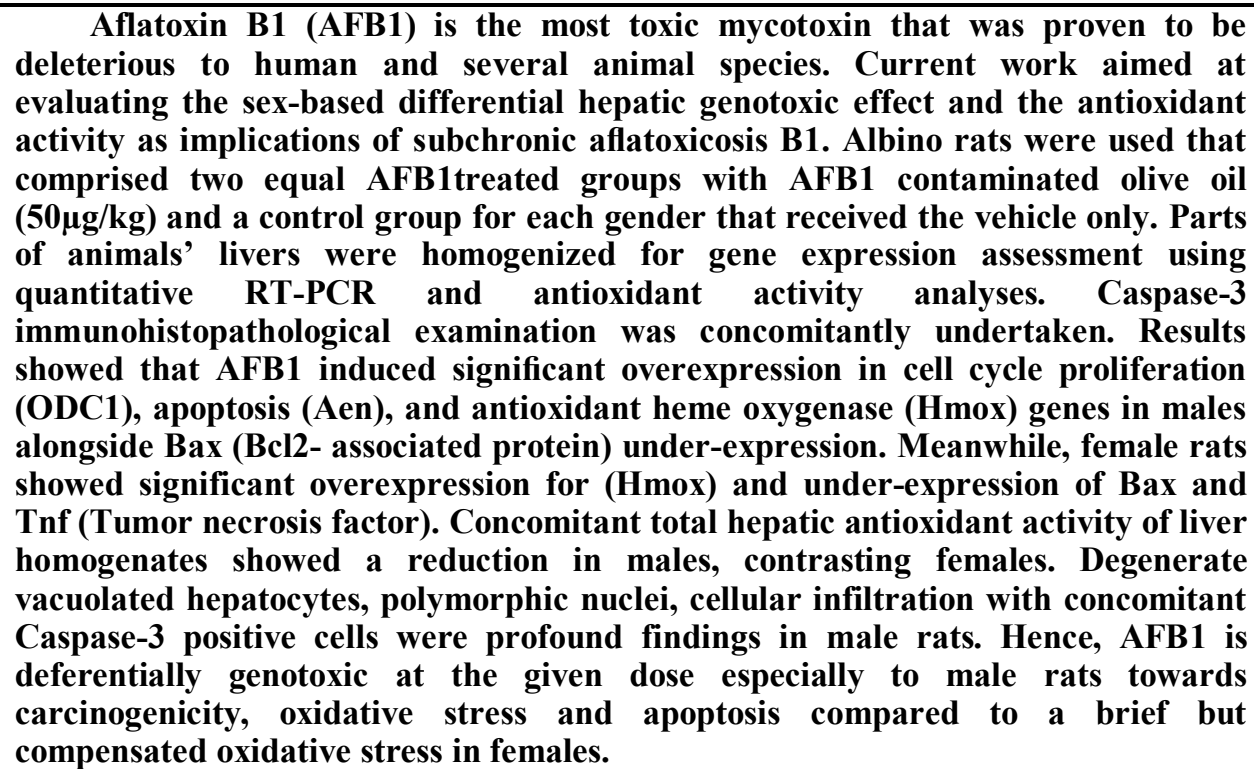 \\
\hline
\end{tabular}

\section{Introduction}

Aflatoxins are a class of mycotoxins that are natural secondary metabolites of fungi (Aspergillus parasiticus and Aspergillus flavus) commonly contaminating food staff especially cereals. Human exposure comes

\footnotetext{
${ }^{(1)}$ Forensic Medicine \& Clinical Toxicology Department, Faculty of Medicine, Assiut University, Assiut, Egypt.

Email: ghada ali@hotmail.com; ghada.omran@aun.edu.eg

${ }^{(2)}$ Chemistry Department, Faculty of Science, Assiut University, Assiut, Egypt.

(3) Botany and Microbiology Department, Faculty of Science, Assiut University, Assiut, Egypt.

(4) Histology Department, Faculty of Medicine, Assiut University, Assiut, Egypt.

${ }^{(5)}$ Chemistry Department, Faculty of Education and Sciences, Aden University, Aden, Yemen..
}

from ingestions of mycotoxin contaminated food products that may lead to deleterious health effects (Bondy and Pestka 2000; Richard, 2007). Aflatoxin B1 (AFB1) is the most toxic form among other classes and recorded to be hepatotoxic mainly causing toxic hepatitis and hepatocellular carcinoma. Furthermore, its carcinogenicity was proven to many other organs, immunosuppressive, teratogenic and mutagenic in human and several tested animal species (Verma et al., 2004; Kitya et al., 2010; WHO 2011).

Some previous epidemiologic studies have validated aflatoxin-DNA adducts as a risk biomarker of hepatocellular carcinoma (Groopman et al., 2008). Additionally, G 
(guanine): C (cytosine) to $\mathrm{T}$ (thymine): A (adenine) transversion observed in AFB1DNA adducts is found frequently in codon 249 of p53 gene of patients highly exposed to AFB1 and having liver carcinoma (Hussain et al., 2007). Aflatoxin induces hepatotoxicity mainly by the formation of reactive oxygen species (ROS) and consequent oxidative damage (Preetha et al., 2006).

Microarray and quantitative real time PCR results from a previous study undertaken by Yarru and associates, revealed that subchronic intake of aflatoxin B1 contaminated diet $(2 \mathrm{mg} / \mathrm{kg}$ of diet) had led to changes in hepatic gene expression of male boiler checks. Genes coding for specific physiological pathways, including oxidation phosphorylation, detoxification, cell proliferation, immune response, metabolism and antioxidant activities were altered (Yarru et al., 2009). However, sexual dimorphism of gene expression patterns in rodents and humans exposed to AFB1 are still scarce. That is why the current study was implemented to explore certain sex-based differential hepatic gene expression changes related to oxidative DNA damage, apoptosis and cellular proliferation. The total antioxidant capability, histopathological and immunohistochemical alterations in livers of albino rats after subchronic consumption of AFB1 were concomitantly considered.

\section{Material and Methods}

\section{Aflatoxin B1 Extraction and Quantitation}

Aflatoxin B1 was extracted and quantified from a corn strain sample (AUMC 9783) that was contaminated with Aspergillus flavus strains and collected from south Egypt in another previous work. The selected strain was checked for their aflatoxin producing abilities on coconut agar medium (CAM) that proved positive only for AFB1 (Ismail et al., 2016). This was validated using high performance liquid chromatography (HPLC 1200 Series) and fluorescence detector G1321A (Agilent Technologies, Waldbronn, Germany) as described by Abo El-Maali and coworkers (Abo El-Maali et al., 2016).

Briefly, the sample was cultivated on Czapek liquid medium (Samson et al., 2004); composed of ( $\mathrm{g} / 1$ distilled water): $30 \mathrm{~g} / \mathrm{l}$ sucrose, 1g/1 K2 HPO4, 3g/1 NaNO3, 0.5g/1 $\mathrm{MgSO} 4.7 \mathrm{H} 2 \mathrm{O}, \quad 0.5 \mathrm{~g} / \mathrm{K} \quad \mathrm{KCl}, \quad 0.01 \mathrm{~g} / 1$ FeSO4.7H2O; $\mathrm{pH} 6.2 \pm 0.2$, that was fortified by yeast extract $(2 \mathrm{~g} / \mathrm{l})$ and peptone $(10 \mathrm{~g} / \mathrm{l})$ (El-Kady et al., 1991). Later, $50 \mathrm{ml}$ of the liquid medium were added in each of $250 \mathrm{ml}$ sterile Erleynmyer flasks.

After sterilization, each flask was inoculated with three agar discs made from 7day-old cultures on CAM plates. The flasks were then incubated at $28{ }^{\circ} \mathrm{C}$ for 10 days. At the end of incubation period, Aspergillus flavus culture was extracted with chloroform for $24 \mathrm{~h}$ at room temperature. The HPLC (High Performance Liquid Chromatography) mobile phase was acetonitrile: methanol: water (30: 55: $15 \mathrm{v} / \mathrm{v} \%$ ) with a flow rate of $1.5 \mathrm{ml} / \mathrm{min}$ under isocratic condition. Thirty microliter injection volume and $30^{\circ} \mathrm{C}$ column temperature was used. The detection wave lengths were fixed at $365 \mathrm{~nm}$ and $455 \mathrm{~nm}$ for the excitation and emission respectively prior to AFB1 identification and quantitation using appropriate standards.

\section{Experimental Design}

Thirty six adult rats weighing approximately $300 \mathrm{~g}$ (mean $300 \pm 55 \mathrm{~g}$ ) males and $200 \mathrm{~g}$ (mean $200 \pm 30 \mathrm{~g}$ ) females were recruited. All rats were obtained from the Faculty of Medicine's Animal House, Assiut University. Animals were allowed to acclimatize to their environment for one week 
before the experiment. They were housed under controlled environmental conditions at $25{ }^{\circ} \mathrm{C}$ with $12 \mathrm{~h}$ dark/ light cycles and free access to food and water. Animals handling was undertaken according to the National Institute of Health guidelines for animal care as stated in the institutional animal care and use committee guidebook and appropriate ethical approval from Faculty of Medicine Ethical Committee in Assiut University.

The rats were divided into two main groups (a control group and an experimental group for each gender). The first main group (control) was subdivided into two subgroups ( 8 male and 8 female rats per group) and the second main group (experimental), were subdivided into two subgroups (10 male rats and 10 female rats per group). The rats were orally gavaged with $50 \mu \mathrm{g} / \mathrm{kg}$ of the AFB1 (Meki et al., 2001). The amount given to each rat was one ml of olive oil only for the control group and one ml of olive oil mixed with aflatoxin $\mathrm{B} 1$ to the experimental group matching designated dose. Rats were gavaged for 90 days ( 5 days/week) and afterwards were sacrificed by neck dislocation for harvesting livers by end of this period. Parts of recovered fresh livers have been processed immediately for the histopathological analyses and the rest were rapidly saved at $-80{ }^{\circ} \mathrm{C}$ for other downstream RNA and antioxidant activity applications.

\section{RNA Extraction and Quantification}

RNA (ribonucleic acid) was isolated and purified from the liver samples using the PureLink $^{\circledR}$ RNA Mini Kit (Ambion, Life Technologies, California, USA) according to the manufacturer recommendations with slight modifications. Briefly, 25-30 mg liver pieces were homogenized by a manual sterilized mortar then $0.6 \mathrm{ml}$ lysis buffer plus 2mercaptoethanol were added. The mixture was vortexed for at least 40 seconds. After that, one volume $70 \%$ ethanol was added to each volume of cell homogenate and vortexed to mix thoroughly and to disperse any visible precipitate that may form after adding ethanol. The rest of the procedure was undertaken as per manufacturer recommendations. The purity and quantity of RNA were determined by a spectrophotometer (Genequant 1300, Biochrom, England) using UV absorbance at 260/ $280 \mathrm{~nm}$.

\section{Quantitative Real Time PCR}

The primers (Invitrogen, Life Technologies, USA) used in current study were of five genes as members of oxidative stress, DNA damage, immunity, apoptosis and cellular proliferation genes (Lin et al., 2002; Suenaga et al., 2013), in addition to a housekeeping gene as shown in table (1). One step reverse transcription (RNA to cDNA) and quantitative real time PCR (RT-qPCR) with SYBR green technology were performed in a real time PCR machine (MxP3000, Stratagene, Germany) using SensiFAST ${ }^{\text {TM }}$ SYBR ${ }^{\circledR}$ HIROX one step kit (Bioline, USA) and the above mentioned primers. The manufacturer recommendations were followed with minor modifications as using half volumes of master mix components (total volume is $10 \mu \mathrm{l}$ ). A three step cycling conditions was followed (one cycle at $45^{\circ} \mathrm{C}$ for $10 \mathrm{~min}$ for reverse transcription, one cycle at $95^{\circ} \mathrm{C}$ for $2 \mathrm{~min}$ for polymerase activation and 40 cycles at $95^{\circ} \mathrm{C}$ for $5 \mathrm{~s}$ (denaturation), $60^{\circ} \mathrm{C}$ for $10 \mathrm{~s}$ (annealing) and $72^{\circ} \mathrm{C}$ for $5 \mathrm{~s}$ (extension). A melt profile analysis was implemented to protect specificity of primers and PCR products. Data were analyzed using the $\Delta \Delta \mathrm{Ct}$ method (Livak and Schmittgen 2001). Each RNA sample was also analyzed for Gapdh gene expression, which served as an internal control for correcting relative specific gene expression levels. 
Table (1): Gene names, functions and real time PCR primers, annealing temperatures used in gene expression analysis in livers of rats exposed to AFB1alongwith their controls.

\begin{tabular}{|c|c|c|c|c|c|c|}
\hline Gene name & Symbol & Forward primer & Reverse primer & Gene category & $\begin{array}{c}\text { Annealing } \\
\text { temperature }\end{array}$ & References \\
\hline $\begin{array}{l}\text { Glyceraldehyde- } \\
\text { 3- phosphate } \\
\text { dehydrogenase }\end{array}$ & Gapdh & $5^{\prime}$-atggccttccgtgttcctaccc-3' & $5^{\prime}$-gcctgcttcaccaccttcttgatg-3' & Housekeeping gene & $53^{\circ} \mathrm{C}$ & $\begin{array}{c}\text { Suenaga et al., } \\
2013\end{array}$ \\
\hline $\begin{array}{l}\text { Heme oxygenase } \\
\text { (decycling) } 1\end{array}$ & Hmox & $5^{\prime}$-caagcacagggtgacagaagagg- 3 , & 5'-tctgtgagggactctggtctttgtg-3' & $\begin{array}{l}\text { Oxidative stress, DNA } \\
\text { damage apoptosis, cell } \\
\text { proliferation, }\end{array}$ & $54^{\circ} \mathrm{C}$ & $\begin{array}{c}\text { Suenaga et al., } \\
2013\end{array}$ \\
\hline $\begin{array}{c}\text { Ornithine } \\
\text { decarboxylase } 1\end{array}$ & OCD1 & 5'-agcagaccggctcggacgat-3' & 5'-agacatgggcagagtgccaa-3' & $\begin{array}{l}\text { Cell cycle proliferation, } \\
\text { rate- limiting step in } \\
\text { pathway of } \\
\text { polyamine } \\
\text { biosynthesis }\end{array}$ & $51^{\circ} \mathrm{C}$ & Lin et al., 2002 \\
\hline $\begin{array}{l}\text { Bcl2- associated } \\
\text { protein }\end{array}$ & Bax & 5'-ggcgaattggagatgaactgg-3' & 5'-gttgaagttgccatcagcaaac-3' & $\begin{array}{c}\text { Apoptosis, cell cycle, cell } \\
\text { proliferation, DNA } \\
\text { damage }\end{array}$ & $48^{\circ} \mathrm{C}$ & $\begin{array}{c}\text { Suenaga et al., } \\
2013\end{array}$ \\
\hline $\begin{array}{c}\text { Apoptosis } \\
\text { enhancing } \\
\text { nuclease }\end{array}$ & Aen & 5'-gcactgcacaatgacttccag-3' & 5'-gccaggtccttaagagagaccc-3' & Apoptosis, DNA damage & $51^{\circ} \mathrm{C}$ & $\begin{array}{c}\text { Suenaga et al., } \\
2013\end{array}$ \\
\hline $\begin{array}{l}\text { Tumor necrosis } \\
\text { factor (Tnf } \\
\text { superfamily, } \\
\text { member 2) }\end{array}$ & Tnf & 5 '-gctgagctcaagccctggtatg-3' & 5'-cccggactccgtgatgtctaag- 3 ' & $\begin{array}{c}\text { Immunity, apoptosis, cell } \\
\text { proliferation }\end{array}$ & $53^{\circ} \mathrm{C}$ & $\begin{array}{c}\text { Suenaga et al., } \\
2013\end{array}$ \\
\hline
\end{tabular}

\section{Total Antioxidant Activity Assay}

The total antioxidant activity was determined using a colorimetric method via the Total Antioxidant Capacity kit (Biodiagnostic, ARE) according to the manufacturer's instructions. The assay of the antioxidant capacity is determined by the reaction of antioxidants in liver homogenate samples (like catalase, superoxide dismutase, and glutathione peroxidase; macromolecules such as albumin, ferritin and ceruloplasmin and a collection of small molecules, including $\beta$ carotene,_ascorbic acid, $\alpha$-tocopherol, reduced glutathione, uric acid, and bilirubin) with exogenously provided hydrogen peroxide. The antioxidants in the sample eliminate a certain amount of $\mathrm{H}_{2} \mathrm{O}_{2}$ and the rest is detected colorimetrically by an enzymatic reaction which involves the conversion of 3,5 , dichloro-2-hydroxy benzensulphonate to a colored product (Abdel-Aziem et al., 2014).

Frozen liver tissue samples were thawed, weighed and homogenized by an automated tissue homogenizer in $5 \mathrm{ml}$ cold buffer $(50 \mathrm{mM}$ potassium phosphate, $\mathrm{pH} 7.5$, containing $0.9 \%$ sodium chloride and $0.1 \%$ glucose) per gram tissue. The homogenates were centrifuged at $4000 \mathrm{rpm}$ for $15 \mathrm{~min}$ at $4^{\circ} \mathrm{C}$, and then the supernatant was removed for assay on UVVisible spectrophotometer (Pharmacia LKB Ultrospec III UV/Vis Spectrophotometer, Biochrom, England) at $505 \mathrm{~nm}$. Total antioxidant concentration was calculated as $\mathrm{mM} / \mathrm{L}=\mathrm{AB}-\mathrm{ASA} \times 3.33$ where, $\mathrm{AB}$ : blank absorbance, ASA: sample absorbance. 
Histopathological and Immunohistochemical Examination

Approximately $0.5-\mathrm{cm}^{3}$ pieces from the freshly isolated liver tissue from all rats were prepared by a frozen section technique using a cryostat instrument (Leica Biosystems, Newcastle, UK) for $10 \mathrm{~min}$ at $-20^{\circ} \mathrm{C}$ to cut 5$8 \mu \mathrm{m}$-thick sections. The procedure followed in such technique was according to Bancroft and Gamble (2008). Then, the obtained sections were stained with Hematoxylin and Eosin for the general histopathological structure using a light microscope (Olympus $\mathrm{CH}$, Japan). For immunohistochemical examination, primary antibody Caspase-3 (CPP32) Ab-4: rabbit polyclonal antibody (Thermo Fisher Scientific, USA) in 1:100 dilution was utilized. Another anti-caspase-3 Biotinylated Goat Antipolyvalent secondary antibody (Abcam, USA) in a dilution of 1:100 was used for the detection of hepatic caspase-3 according to Hofman and Taylor (Hofman and Taylor, 2013). For a negative control staining, some sections were incubated with PBS instead of the primary antibody. For a positive control, a section of a control tonsil was used.

\section{Statistical Analysis}

Fold changes in expression of used genes were calculated by $\Delta \Delta \mathrm{Ct}$ method; where fold change $=\log 2^{-\Delta \Delta \mathrm{Ct}}$ and $\Delta \Delta \mathrm{Ct}=(\mathrm{Ct}$ of target gene - Ct of Gapdh gene) treated- (Ct of target gene - Ct of Gapdh gene) control. A two tailed - Student $t$ test with unequal group variance was used to compare 2- $\Delta \Delta \mathrm{Ct}$ genetic expression differences (Schmittgen and Livak, 2008) in male and female rats compared to their matched controls. Additionally, the antioxidant capacity differences between controls and fed rats from each gender and gene fold differences between treated male and female rats were analyzed. SPSS IBM Statistics software version 22 (IBM, NYC, New York, USA) was implemented. Data was expressed as means \pm SD (standard deviation). Significance values were set $<0.05$ level.

\section{Results}

\section{Gene Expression Changes}

The five genes examined in rats' livers showed differential expression patterns between controls and AFB1 treated rats from each gender in one side and between gavaged males versus females from the other side. Figure (1) shows gender differentially expressed five genes (Hmox, Tnf, Aen, Bax and ODC1). Three genes were significantly upregulated in male rats (Aen, ODC1 and Hmox) with fold changes of 2.086, 3.016 and 1.5901 respectively. Meanwhile, Bax was significantly down regulated with a ratio of 0.732 (expression is reduced by 1.366 folds due to AFB1 treatment according to Schmittgen and Livak's formula through taking the negative inverse of $2^{-\Delta \Delta \mathrm{Ct}}$ ), and the remaining gene (Tnf) showed no significant change relative to their controls. On the other hand, female rats showed considerable overexpression in Hmox gene with ratios of 1.855 and under expression of Tnf and Aen with ratios of 0.719 and 0.775 in that order (fold decrease by 1.39 and 1.29 respectively relative to their female controls). 


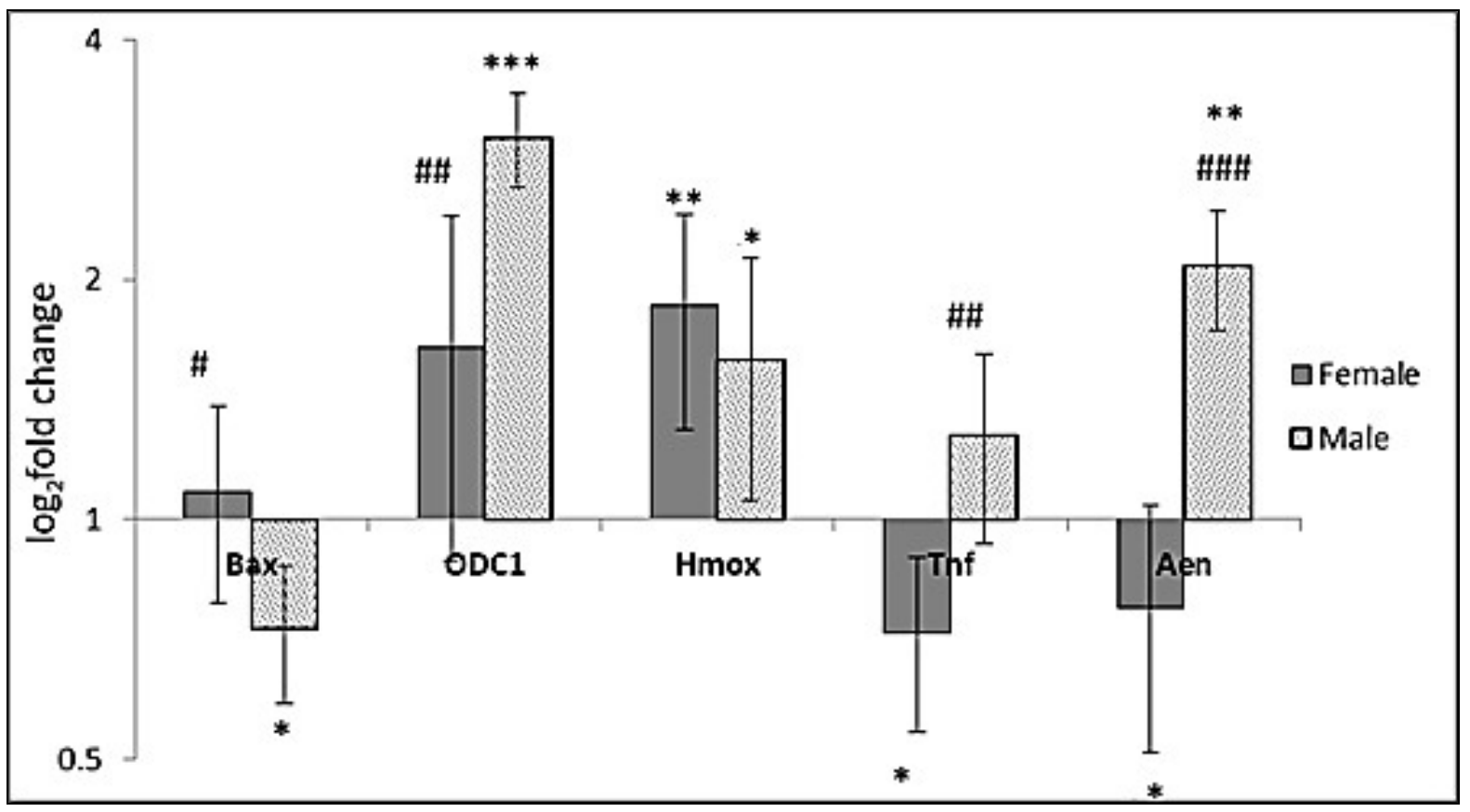

Fig. (1): Quantitative real time PCR fold changes of hepatic gene expression in male versus female rats treated with $\mathrm{AFB} 1$ and relation of each gender to its controls using $\Delta \Delta \mathrm{Ct}$ method. TNF: Tumor necrosis factor; ODC1: Ornithine decarboxylase 1; Bax: Bcl2-associated X protein; Aen: Apoptosis enhancing nuclease; Hmox: Heme oxygenase. Intersection of $\mathrm{Y} \& \mathrm{X}$ axes was adjusted to one to display gene up or down regulation in relation to control ratios. Error bars represent $\pm \mathrm{SD}$ (standard deviation). $* \mathrm{p}<0.05, * * \mathrm{p}<0.01 ., * * * \mathrm{p}<0.001$ were used for significant difference of each gender with its control; for significant gene expression fold changes in male versus female rats, \# $\mathrm{P}<0.05$, \#\#P<0.01, \#\#\#P<0.001 were used.

Regarding the differential gene expression pattern in male rats treated with aflatoxin B1 compared to their matching female counterparts, a two tailed Student ttest was implemented. Statistically significant differences were observed in Aen, ODC, Tnf and Hmox genes. Major variation was observed in Aen and Tnf genes. They were up regulated in males in contrary to females while the Bax gene was significantly different from males towards upregulation. Ornithine decarboxylase (ODC1) gene was significantly more expressed in males than females with no considerable differentiation in both sexes in Hmox gene as well.

\section{Total Antioxidant Activity}

The total antioxidant activity of liver homogenates was analyzed using $t$-test in comparing AFB1 treated groups to controls from each gender. Figure (2) displayed significantly decreased antioxidant activity in males compared to their parallel controls ( $p$ value $=0.0318$ ). On the contrary, females showed a mild increase in antioxidant activity but with no significant difference from controls ( $\mathrm{p}$ value $=0.763$ ). 


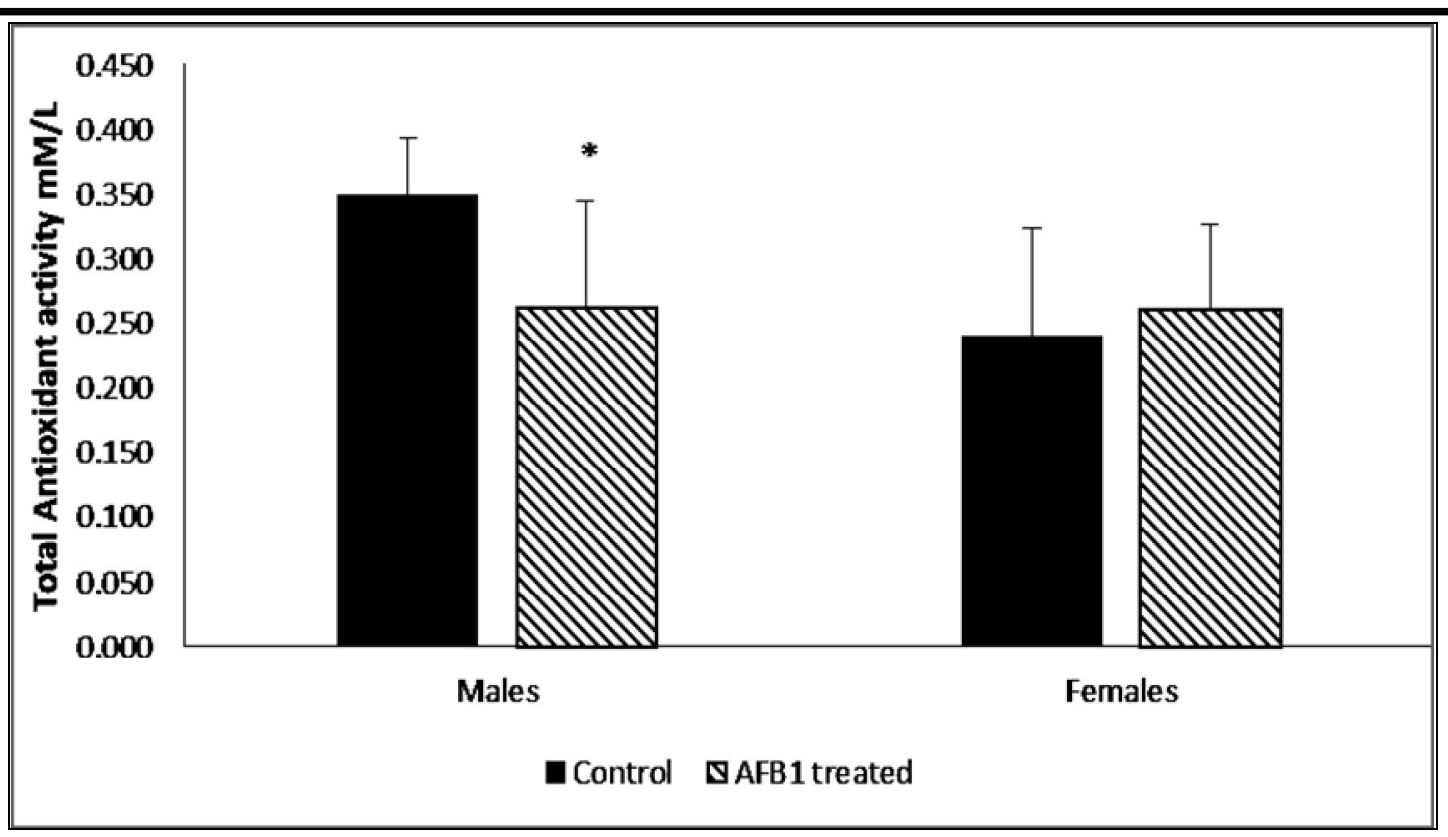

Fig. (2): Total antioxidant activity in liver homogenates of male and female rats treated with aflatoxin B1 compared to their controls. Bars represent mean antioxidant values, Error bars represent $+\mathrm{SD}$ (Standard deviation), ${ }^{*} \mathrm{p}<0.05$.

\section{Histopathology and Immunohistochemistry}

The histopathological examination was assessed by a light microscope using Hematoxylin and Eosin stains and Caspase-3 immunostaining in male livers revealed the following:

1- Control: The liver sections showed normal hepatic structure. The liver was formed of lobules. Each lobule was characterized by the presence of a central vein and portal areas at the periphery. The hepatocytes were arranged into plates radiating from the central vein. They were polyhedral with acidophilic cytoplasm. They had large rounded central vesicular nuclei with prominent nucleoli (Figure 3-A).
2- Aflatoxin B1(AFB1) treated: many liver cells appeared degenerated with vacuolated cytoplasm. The nuclei showed polymorphism and some of them appeared hyperchromatic while others showed irregularly sized nuclei (Figure 3-B). Localized areas of cellular infiltration were also observed (Figure 3-C).

3- Caspase-3 immunostaining for detection of apoptosis in controls showed a mild positive reaction in some liver cells (Figure 3-D)while AFB1 treated males displayed a highly positive reaction in many cells (Figure 3-E and F). 


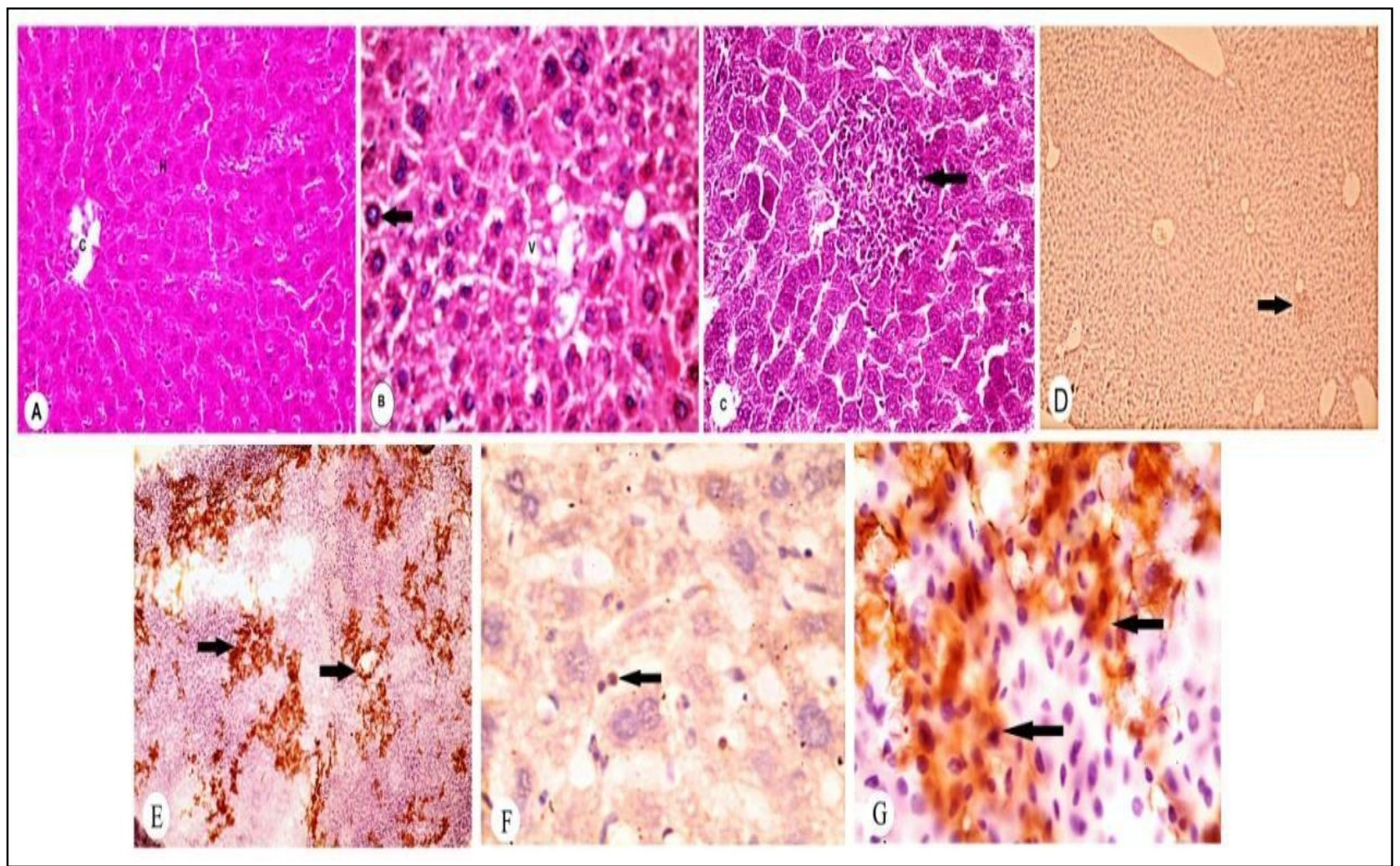

Fig. (3): Hepatic histopathological and immunohistochemical examinations of Aflatoxin B1treated and controls of male rats. A: controls showed a normal hepatic structure. The liver was formed of lobules. Each lobule is characterized by presence of central vein $(C)$ in the center. The hepatocytes $(\mathrm{H})$ were arranged in plates radiating from the central vein. $\mathrm{B}$ : in AFB1 treated rats, many liver cells appear degenerated with vacuolated cytoplasm (V). The nuclei showed polymorphism (arrow). Some nuclei appeared hyperchromatic while others showed irregular sized nuclei. C: Localized area of cellular infiltration was also observed (arrow) in AFB1 treated group. With Caspase-3 immunostaining: in D \& F; there is mild positive reaction in some liver cells in controls (arrow). In E \& G: a highly positive reaction was observed in many cells in AFB1 treated rats (arrow). A, B, C: stained with $\mathrm{H} \& \mathrm{E}$ x400. D, E, F, G: caspase-3 immunostaining, D \& E x 100, F \& G x1000.

Light microscopic examination of the female livers revealed the following by use of Hematoxylin and Eosin stains and Caspase 3 immunostaining:

1-Control: The liver sections showed a normal hepatic structure which was nearly the same as the male liver (Figure 4-A).

2-Aflatoxin B1(AFB1) treated: showed minimal vacuolation in liver cells with mild cellular infiltration compared to the male. Nuclear polymorphism was not observed. (Figure 4-B).

3-Caspase-3 immunostaining for detection of apoptosis exhibited a nearly negative reaction in liver cells of controls (Figure 4-C and E), while AFB1 treated females displayed a moderate positive reaction in some liver cells (Figure 4-D and F). 


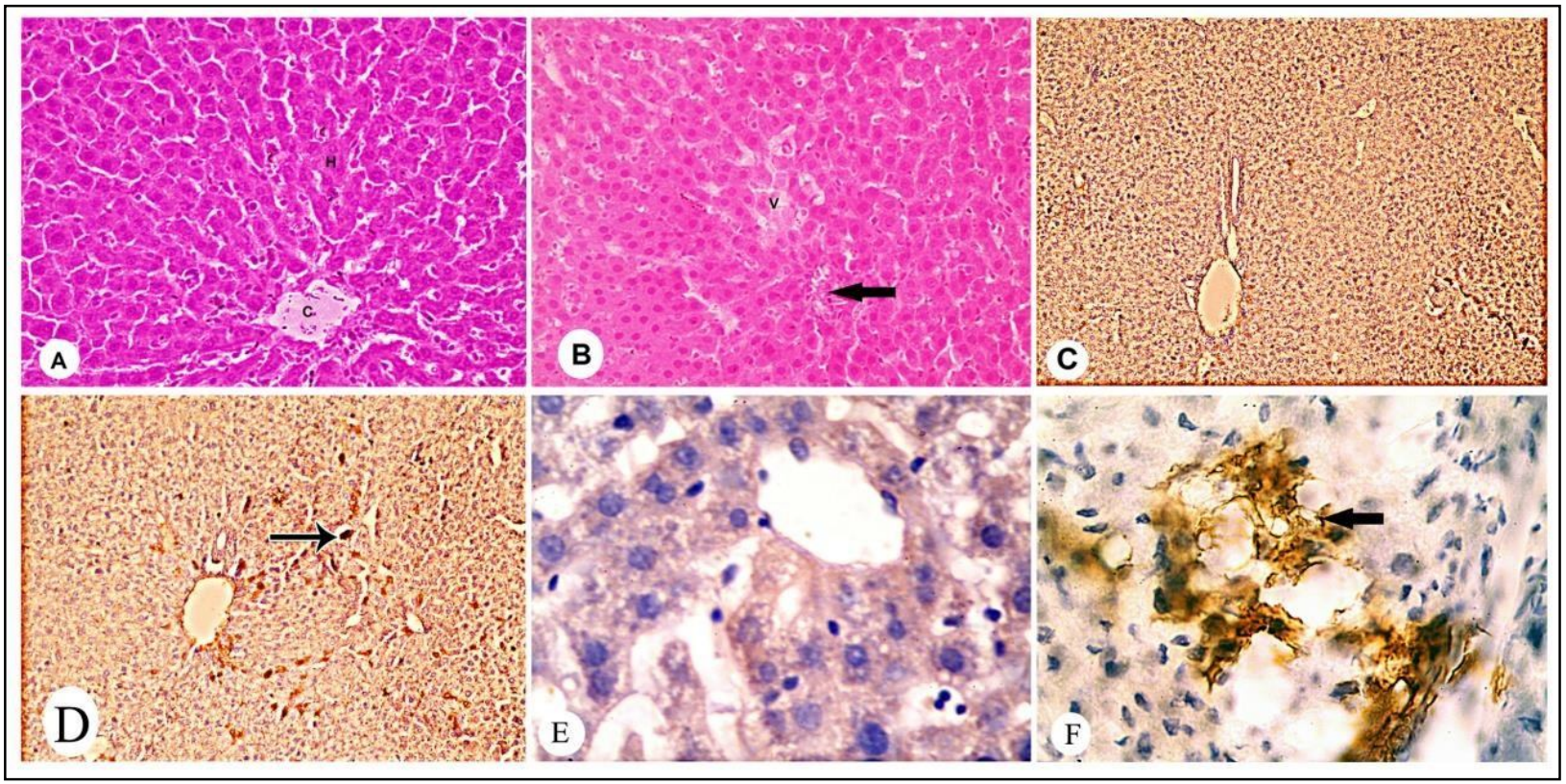

Fig. (4): Hepatic histopathological and immunohistochemical examinations of Aflatoxin B1 treated and controls of female rats. A: controls showed normal hepatic structure. The liver was formed of lobules. Each lobule was characterized by presence of central vein (C) in the center. The hepatocytes $(\mathrm{H})$ were arranged in plates radiating from the central vein. B: AFB1 treated rats, showed minimal vacuolation (V) in liver cells with mild cellular infiltration (arrow) compared to males. Nuclear polymorphism was not observed. With Caspase-3 immunostaining: in C\&E there was nearly a negative reaction in liver cells of controls. In D\&F: a moderate positive reaction was observed in some cells of AFB1treated rats (arrow). A,B: stained with H\&E x400. C, D, E, F: caspase-3 immunostaining. C\&D x100, E\&F x1000.

\section{Discussion}

Liver is considered the main target organ for aflatoxicosis (Yildirim et al., 2011). Aflatoxin B1 (AFB1) is a potent hepatotoxic and hepatocarcinogenic mycotoxin. It has been postulated to mediate various deleterious effects in tissues through the induction of oxidative stress (Özen et al., 2009). Investigation of gender based gene expression and antioxidant activity in response to AFB1exposure were considered in rat liver. Subchronic treatment of albino rats with AFB1 resulted in a well differentiated hepatic gene expression response in each gender.

The observed upregulation of ornithine decarboxylase (ODC1) gene, especially in male rats, could contribute to increased cellular proliferation rates predisposing to hepatocellular carcinomas as could be observed in previous studies of rats (Yarru et al., 2009) and boiler checks livers (Butler et al., 1981). Ornithine decarboxylase (OCD1) was overexpressed in many cancers like human colon, liver (Tomasi et al., 2013), and breast carcinomas (Xu et al., 2015) as well. Overexpression observed in male rats along with hepatic histopathological characterization of possible precancerous foci may potentiate future carcinogenesis. This hepatocarcinogenic potency of AFB1 especially in rats given single or divided doses was described previously in many reports (Haddad, 1998). Noteworthy, this carcinogenic behavior was recorded to be much higher in males in both 
experimental animals and humans supporting current findings (Woo et al., 2011). The observed sexual dimorphism in gene expression can be attributed to female estrogenic hormones that can suppress inflammation and reduce cancer risk during early phases of hepato-carcinogenesis (Naugler et al., 2007).

There was an increase in the apoptotic pathway as can be deduced from significant upregulation of Apoptosis enhancing nuclease (Aen). The latter is an exonuclease that mediates p53-induced apoptosis. When induced by $\mathrm{p} 53$ following DNA damage, it digests double-stranded DNA into singlestranded DNA and intensifies DNA damage signals, leading to enhancement of apoptosis (Suenaga et al., 2013). On the other hand, other apoptosis, oxidative stress and DNA damage contributing genes were either significantly elevated comparative to control males (Hmox) or only showed trivial increment like the Tnf gene, paralleling recent studies on male rats and mice that were given similar genotoxic hepatocarcinogens within 48 $\mathrm{h}$ of exposure (Watanabe et al., 2007; Watanabe et al., 2009; Watanabe et al., 2012; Suenaga et al., 2013). Noteworthy, the proapoptotic Bax gene was downregulated in males despite overexpression of other apoptosis enhancing genes (Aen). This has been reported before as a result of nonfunctional p53 overexpression in hepatocellular carcinomas (Beerheide et al., 2000). A reduced Bax expression had also been described in many human tumors, such as cervical (Soufla et al., 2005) and ovarian cancers (Tai et al., 1998). Analyses of apoptosis-related genes showed that Aen and Bax were the main targets in hepatic apoptosis induction in response to the hepatocarcinogen aminoanthracene exposure in a time dependent manner, where Bax was observed in short term high dose exposure and Aen was detected late, more with medium doses (Gato et al., 2014).
This latter gene upregulation was found important to both the short and long-term apoptotic response to AFBlin low or high doses given to growing barrows among other screened apoptosis gene expression changes in that study (Rustemeyer et al., 2011).

The genetic effects observed were consistent to the depressed total antioxidant capacity of liver homogenates versus controls. This in part confirmed previous findings as regard enhancement of apoptotic changes and decrease in liver antioxidant enzymes, increase in malondialdehyde and nitric oxide levels in chronically AFB1 treated male rats with a similar dose ( Meki et al., 2001; Rastogi et al, 2001; Theumer et al., 2010; Yang et al., 2012).

Aflatoxin B1 treated female counterparts showed a slight elevation of some genes like OCD1, Bax and a significant change in Hmox with concomitant increment in antioxidant levels although statistically insignificant when compared to controls. Heme oxygenase expression was induced in response to oxidative stress, as a protective behavior in animal models (Kikuchi et al., 2005). Meanwhile, Tnf and Aen were downregulated indicating a possible compensated oxidative stress in this species given that dose to resist apoptosis and DNA damage.

To our knowledge, no previous reports available that have considered genotoxic behavior of AFB1 in female rats. Lack of a significant change though increased antioxidant activity in treated females may be attributed to the complexity of endogenous systems involved in correction and repair. This may occur when a brief increase in oxidative stress rapidly induces compensatory different antioxidant activities that limit the stress and the ability to detect a noticeable alteration by chemical testing methods like the absence of modifications in $\mathrm{H} 2 \mathrm{O} 2$ release in detection method used (Blumberg, 2004). This could be a consequence of higher scavenging of ROS 
(reactive oxygen species) by antioxidant enzymes induced by persistent aggression of the mycotoxins (Theumer et al., 2010; AbdelAziem et al., 2014).

Regarding the immunohistopathological examination, we found vacuolar degeneration in the liver cells of male rats in addition to many caspase- 3 positive cells indicating the occurrence of apoptosis. This finding was similar to previous studies, which reported a dose-dependent vacuolar degeneration with various severity showing irregularly shaped vacuoles in hepatocytes as signs of fatty accumulation (Özen et al., 2009). Moreover, vacuolar degeneration reported could be related to impaired lipid transport rather than increased lipid biosynthesis (McLean and Dutton, 1995).

Localized areas of cellular infiltration were observed, especially in male rats. This can be explained through the aflatoxins primary affection of cellular immunity process in most animal species (Oğuz et al., 2002). In the AFB1-exposed chickens, Yildirim et al. (2011) have declared mild mononuclear cell infiltration in the liver's portal areas. Small inflammatory cell infiltrates encompassing mononuclear cells, lymphocytes, plasma cells, and few segmented neutrophils occur to respond to degenerate vacuolated hepatocytes (Hinton, 2003).

Nuclear polymorphism mainly in male hepatocytes was observed as well, some nuclei appeared hyperchromatic while others showed irregular size. This could be elucidated as aflatoxin is metabolized by hepatic cytochrome P450 enzyme system to produce a highly reactive intermediate, aflatoxin 8, 9epoxide, which consequently binds to in the hepatocyte DNA nucleophilic sites to form adducts (Smela et al., 2001), thus damaging the liver cells structure (Pasha et al., 2007; Kumar and Balachandran, 2009). These DNA adducts subsequently lead to heritable genetic alterations that drive the hepatocyte in the direction of transformation (Ho et al., 2016) and initiation of aflatoxin B1-induced hepatocarcinogenesis (Preston and Williams, 2005).

In female rats, there was mild liver affection in the form of minimal vacuolation with mild cellular infiltration and moderate caspase-3 positive reaction in some cells compared to males. Nuclear polymorphism was not observed. Increased expression of caspase-3, especially in males, might be explained by its different functions, which are involved in immune and inflammatory reactions to apoptotic dying cells. Upon caspase- 3 activation, different proteins related to cell structural integrity are cleaved (Galluzzi et al., 2016).

The present study had underlined sexrelated differences in aflatoxin B1 induced toxicity. A milestone study carried out by Kamdem et al. (1982) reported a difference in drug-metabolizing enzymes in the two sexes when exposed to different doses of AFB1. Those hepatic enzymes showed higher basal activities in males versus females. Notably, after AFBI treatment, the levels of enzyme activities became higher in females and the detoxification system was more competent and protective against deleterious aflatoxin metabolites, contrasting males. Moreover, it had been reported that the drug-metabolizing and transporter genes in the human liver showed a sex-based differential pattern. The female predominantly expressed CYP3A4, the most essential cytochrome P450 catalyst of drug metabolism in the human liver. This sexual dimorphic expression of hepatic P450s and other genes is regulated mainly by the release of plasma growth hormone $(\mathrm{GH})$ in a temporal pattern. The latter showed a pulsatile release manner in male rats and mice versus nearly a continuous pattern among females (Waxman and Holloway, 2009) which in turn, can introduce differences in drug absorption, metabolism, excretion, and possibly affecting the higher adverse AFB1 reactions in male rats (Yang et al., 2012). 


\section{Conclusion}

It could be concluded that AFB1 was differentially genotoxic at the given dose especially to male rats towards carcinogenicity, oxidative stress and apoptosis compared to brief but compensated oxidative stress in females. Further studies may focus on different dose regimens in either sex alongside addressing the mechanism underlying such sex-based different response to AFB1 exposure. Moreover, follow up of gene expression associated changes in protein levels or activity, is highly desired concurrently with assessment of genotoxicity endpoints like oxidative DNA damage- related p53 activation.

\section{Acknowledgements}

Authors are grateful to the partial support of this work by a scholarship from Yemeni government. We also thank the laboratory staff for their valuable help in conduction of this research within the Clinical Toxicology \& Forensic Chemistry laboratory and the Molecular Biology Research Unit of Assiut University. Authors would like also to express deep appreciation to Dr. Mohammad Kamal, representative of Life Technologies Company for his valuable help in RT-PCR statistical evaluation.

\section{References}

Abdel-Aziem, S.H.; Hassan, A.M.; ElDenshary, E.S.; et al. (2014): "Ameliorative effects of Thyme and Calendula extracts alone or in combination against Aflatoxins-induced oxidative stress and genotoxicity in rat Liver". Cytotechnology, 66 (3): $457-$ 470.

Abo El-Maali, N.T.; Ismail, M.A.; Omran, G.A. et al. (2016): "Optimization of HPLC with fluorescence detection for the assay of Aflatoxins from Aspergillus strains of section Flavi originated from grains in Upper Egypt”. Assiut Uni. J. of Chem., 45: 135-145.

Bancroft, J. D. and Gamble, M. (Eds) (2008): Theory and Practice of Histological Techniques. 6th ed, China: Churchill Livingstone, Elsevier Health Sciences.

Beerheide, W.; Tan, Y.J.; Teng, E.; et al. (2000): "Downregulation of proapoptotic proteins Bax and Bcl-XS in P53 overexpressing hepatocellular carcinomas". Biochem. Biophys. Res. Commun., 273 (1): 54-61.

Blumberg, J. (2004): "Use of biomarkers of oxidative stress in research studies". J. Nutr., 134 (11): 3188S-3189S.

Bondy, G. S., and Pestka, J. J. (2000): "Immunomodulation by fungal toxins". J. Toxicol. Environ. Health B. Crit. Rev., 3 (2): 109-143.

Butler, W.H.; Hempsall, V. and Stewart, M.G. (1981): "Histochemical studies on the early proliferative lesion induced in the rat liver by Aflatoxin". The J. Path., 133 (4): 325-340.

El-Kady, I., A.; El-Maraghy, S. M. and Zohri., A. A. (1991): "Mycotoxin production on different cultivars and lines of broad bean (Vicia Faba L.) seeds in Egypt". Mycopathologia, 113 (3): 165-169.

Galluzzi, L.; López-Soto, A.; Kumar, S. and Kroemer, G. (2016): "Caspases connect cell- death signaling to organismal homeostasis". Immunity, 44 (2): 221231.

Gato, W.E.; McGee, S.R.; Hales, D.B. et al. (2014): "Time-dependent regulation of apoptosis by Aen and Bax in response to 2-Aminoanthracene dietary consumption". Toxicol. Int., 21 (1): 58. 
Groopman, J. D.; Kensler, T. W. and Wild, C. P. (2008): "Protective interventions to prevent Aflatoxin - induced carcinogenesis in developing countries". Annu. Rev. Pub. Health., 29: 187-203.

Haddad, L. M. (1998): Clinical management of poisoning and drug overdose. 3rd ed. Philadelphia, PA: W.B. Saunders Co.

Hinton, D.M.; Myers, M.J.; Raybourne, R.A.; et al. (2003): "Immunotoxicity of Aflatoxin B1 in rats: effects on lymphocytes and the inflammatory response in a chronic intermittent dosing study". Toxicol. Sci., 73 (2): 362-377.

Ho, D.W.H.; Lo, R.C.L.; Chan, L.K.; et al. (2016): "Molecular pathogenesis of hepatocellular carcinoma". Liver Cancer, 5 (4): 290-302

Hofman, F. M, and Taylor C. R. (2013): "Immunohistochemistry. Current Protocols in Immunology". 103 (1): 21.4.1-21.4.26. https://doi.org/10.1002/0471142735.im2 $\underline{104 \mathrm{~s} 103}$.

Hussain, S. P.; Schwank, J.; Staib, F.; et al. (2007): "TP53 mutations and hepatocellular carcinoma: insights into the etiology and pathogenesis of liver cancer." Oncogene, 26 (15): 2166-2176.

Ismail, M. A.; Abo El-Maali, N. T.; Omran, G.A.; et al. (2016): "Biodiversity of Mycobiota in peanut Seeds, corn and wheat grains with special reference to their Aflatoxigenic ability". J. Microb. Biotech. Food. Sci., 5 (4): 314-319.

Kamdem, L.; Siest, G. and Magdalou, J. (1982): "Differential toxicity of Aflatoxin B1 in male and female rats: relationship with hepatic drugmetabolizing enzymes". Biochem. Pharma., 31 (19): 3057-3062.
Kikuchi, G.; Yoshida, T. and Noguchi, M. (2005): "Heme oxygenase and heme degradation". Biochem. Biophys. Res. Commu., 338 (1): 558-567.

Kitya, D., Bbosa, G. S.; and Mulogo, E. (2010): "Aflatoxin levels in common foods of south western Uganda: a risk factor to hepatocellular carcinoma". Eur. J. Cancer. Care (Engl),19 (4): 516-521.

Kumar, R. and Balachandran, C. (2009): "Histopathological changes in broiler chickens fed Aflatoxin and Cyclopiazonic acid". Vet. Arhiv., 79 (1): 31-40.

Lin, C. H.; Vijesurier, R.; Ho, Y. S.; et al. (2002): "Expression of intestinal ornithine decarboxylase during postnatal development in neonatal rats". Biochim. Biophys. Acta, 1589 (3): 298-304.

Livak, K. J.: and Schmittgen, T.D. (2001): "Analysis of relative gene expression data using Real-Time Quantitative PCR and the 2(-Delta Delta CT) method". Methods, 25 (4): 402- 408.

McLean, M. and Dutton, M.F. (1995): "Cellular interactions and metabolism of Aflatoxin: an update". Pharm. \& Therap., 65 (2): 163-192.

Meki, A. R.; Abdel-Ghaffar, S. K. and ElGibaly, I. (2001): "Aflatoxin B1 induces apoptosis in rat liver: protective effect of melatonin". Neuro. Endocrinol. Lett., 22 (6): 417-426.

Naugler, W. E., Sakurai, T.; Kim, S.; et al. (2007): "Gender disparity in liver cancer due to sex differences in MyD88dependent IL-6 production". Science, 317 (5834): 121-124. 
Oğuz, H.; Kurtoğlu, F., Kurtoğlu, V. and Birdane, Y.O. (2002): "Evaluation of biochemical characters of broiler chickens during dietary Aflatoxin (50 and 100ppb) and Clinoptilolite exposure". Res. Vet. Sci., 73 (1): 101103.

Özen, H.; Karaman, M.; Çiğremiş, Y.; et al. (2009): "Effectiveness of melatonin on Aflatoxicosis in chicks". Res. Vet. Sci., 86 (3): 485-489.

Pasha, T.N.; Farooq, M.U.; Khattak, F.M.; et al. (2007): "Effectiveness of sodium bentonite and two commercial products as Aflatoxin absorbents in diets for broiler chickens". Anim. Feed. Sci. Tech., 132 (1-2): 103-110.

Preetha, S.P.; Kanniappan, M.; Selvakumar, E.; et al. (2006): "Lupeol ameliorates Aflatoxin B1-induced peroxidative hepatic damage in rats". Comp. Biochem. Physiol. Toxicol. Pharm., 143 (3): 333-339.

Preston, R.J. and Williams, G.M. (2005): "DNA-reactive carcinogens: mode of action and human cancer hazard". Crit. Rev. Toxicol., 35 (8-9): 673-683.

Rastogi, R.; Srivastava, A. K. and Rastogi, A. K. (2001): "Biochemical changes induced in liver and serum of Aflatoxin B1-treated male Wistar rats: preventive effect of Picroliv". Pharmacol. Toxicol., 88 (2): 53-58.

Richard, J. L. (2007): "Some major mycotoxins and their mycotoxicoses-an overview". Int. J. Food. Microbiol., 119 (1-2): 3-10.

Rustemeyer, S. M.; Lamberson, W. R.; Ledoux, D. R.; et al. (2011): "Effects of dietary Aflatoxin on the hepatic expression of apoptosis genes in growing barrows1". J. Anim. Sci., 89 (4): 916925.
Samson, R. A.; Hoekstra, E. S. and Frisvad, J. C. (2004): Introduction to food- and airborne fungi. $7^{\text {th }}$ Ed. Utrecht: Centraalbureau voor Schimmelcultures, The Netherlands.

Schmittgen, T.D. and Livak, K.J. (2008): "Analyzing Real-Time PCR data by the comparative CT method". Nat. Protoc., 3(6):1101-1108.

Smela, M.E.; Currier, S.S.; Bailey, E.A. et al. (2001): "The chemistry and biology of Aflatoxin B1: from mutational spectrometry to carcinogenesis". Carcinogenesis, 22 (4): 535-545.

Soufla, G.; Baritaki, S.; Sifakis, S.; et al. (2005): "Transcriptional inactivation of P53, Bax, Bcl-2 and Mdm2 correlates with malignant transformation of the uterine cervix". The Int. J. Biol. Markers, 20 (1): 18-27.

Suenaga, K.; Takasawa, H.; Watanabe, T.; et al. (2013): "Differential gene expression profiling between genotoxic and non-genotoxic hepatocarcinogens in young rat liver determined by Quantitative Real-Time PCR and Principal Component analysis". Mutat. Res., 751 (1): 73-83.

Tai, Y.T.; Lee, S.; Niloff, E.; et al. (1998): "BAX protein expression and clinical outcome in epithelial ovarian cancer". J. Clin. Oncol., 16 (8): 2583-2590.

Theumer, M. G.; Canepa, M. C.; Lopez, A. G.; et al. (2010): "Subchronic mycotoxicoses in Wistar rats: assessment of the in vivo and in vitro genotoxicity induced by fumonisins and Aflatoxin $\mathrm{B}(1)$, and oxidative stress biomarkers status". Toxicol., 268 (1-2): 104-110.

Tomasi, M. L.; Ryoo, M.; Skay, A.; et al. (2013). "Polyamine and methionine adenosyltransferase $2 \mathrm{~A}$ crosstalk in 
human colon and liver cancer". Exp. Cell. Res., 319 (12): 1902-1911.

Verma, J.; Johri, T. S.; Swain, B. K.; et al. (2004): "Effect of graded levels of Aflatoxin, Ochratoxin and their combinations on the performance and immune response of broilers". Br. Poult. Sci., 45 (4): 512-518.

Watanabe, T.; Suzuki, T.; Natsume, M.; et al. (2012): "Discrimination of genotoxic and non-genotoxic hepatocarcinogens by statistical analysis based on gene expression profiling in the mouse liver as determined by Quantitative Real-Time PCR". Mutat. Res., 747 (2): 164-175.

Watanabe, T.; Tanaka, G.; Hamada, S.; et al. (2009): "Dose-dependent alterations in gene expression in mouse liver induced by Diethylnitrosamine and Ethylnitrosourea and determined by Quantitative Real- Time PCR". Mutat. Res., 673 (1): 9-20.

Watanabe, T.; Tobe, K.; Nakachi, Y.; et al. (2007): "Differential gene expression induced by two genotoxic N-Nitroso carcinogens, Phenobarbital and Ethanol in mouse liver examined with oligonucleotide microarray and Quantitative Real-Time PCR". Genes. Envir., 29 (3): 115-127.

WHO (2011): "Twelfth report on carcinogens: Aflatoxins, (1402-68-2)." edited by US department of Health and Human Services and Nat. Toxicology Program (NTP) (NIH). Twelfth Ed. WHO.

https://oehha.ca.gov/media/downloads/cr $\mathrm{nr} / \mathrm{ntp} 2011$ roc12.pdf.

Woo, L. L.; Egner, P. A.; Belanger, C. L.; et al. (2011): "Aflatoxin B1-DNA adduct formation and mutagenicity in livers of neonatal male and female B6C3F1 mice”. Toxicol. Sci., 122 (1): 38-44.

Waxman, D. J., and Holloway, M. G. (2009). "Sex differences in the expression of hepatic drug metabolizing enzymes". Mol. Pharmacol., 76(2), 215228.

Xu, L.; Long, J.; Wang, P.; et al. (2015): "Association between the ornithine decarboxylase G316A polymorphism and breast cancer survival". Oncol. Lett., 10(1):485-491.

Yang, J.; Bai, F.; Zhang, K.; et al. (2012): "Effects of feeding corn naturally contaminated with Aflatoxin B1 and B2 on hepatic functions of broilers". Poult. Sci., 91 (11): 2792-2801.

Yang, L.; Li, Y.; Hong, H.; et al. (2012). "Sex differences in the expression of drug-metabolizing and transporter genes in human liver". J. Drug. Metab. \& Toxicol., 3(3),

doi:10.4172/21577609.1000119.

Yarru, L. P.; Settivari, R. S.; Antoniou, E.; et al. (2009): "Toxicological and gene expression analysis of the impact of Aflatoxin B1 on hepatic function of male broiler chicks". Poult. Sci., 88 (2): 360 371.

Yildirim, E.; Yalçinkaya, İ.; Kanbur, M.; et al. (2011): "Effects of yeast Glucomannan on performance, some biochemical parameters and pathological changes in experimental Aflatoxicosis in broiler chickens". Revue. Méd. Vét., 162 (162): 8-9. 


\section{التباين الكبدى فى التعبير الجينى والنشاط المضاد للأكسدة في الجرذان والمحفز بواسطة التسمم شبه

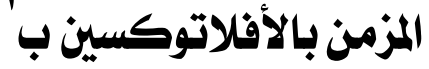

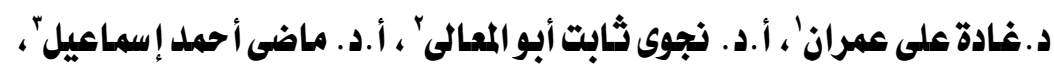

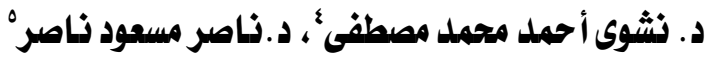

'قسم الطب الثرعى والسموم الإكلينيكية، كلية الطب ، جامعة أسيوط، أسيوط، جمهورية مصر العربية

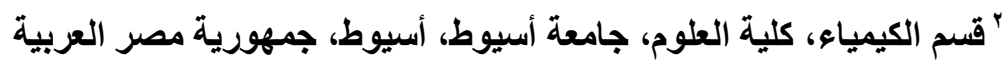

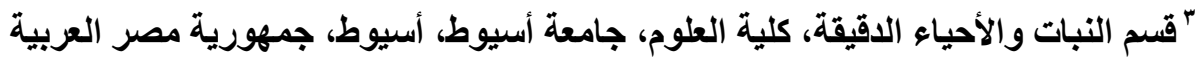

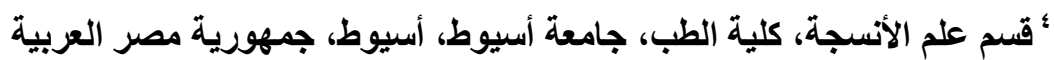

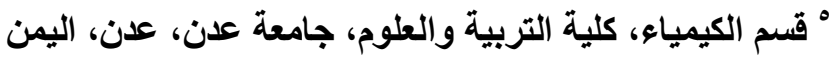

الأفلاتوكسين با هو من السموم الفطرية الأكثر سمية والتي ثبت أنها ضـارة للإنسان والعديد من أنواع

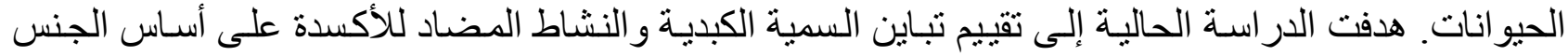
وذلك نتيجة التعرض بصورة شبه مزمنة للأفلاتوكسين ب ا ـ استخدمت الجرذان البيضاء التي تضم مجمو عتين متساويتين من كل جنس ذكور أو إناث حيث تم تجريعهم • م ميكروجر ام/كجم من الأفلاتوكسين ب ا المخلوط مع زيت الزيتون، ومجمو عة ضابطة لكل جنس تجرعت المادة المذيبة فقط. تم هرس أجز اء من أكباد الجرذان من أجل تقييم التعبير الجيني لعدد خمس جينـات باستخدام تفاعل البلمرة المتسلسل الكمي الآنى وتحليل النشاط

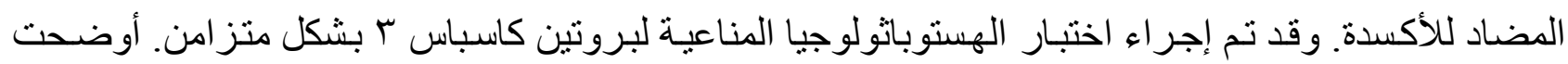
النتائج أن الأفلاتوكسين ب ا أحدث زيادة مفرطة في التعبير الجينى لجين خاص بالدورة الخلويـة (ODC1) ، و آخر خاص بموت الخلايا المبرمج (Aen) ، وجين Hmox المضاد للأكسدة عند الذكور إلى جانب نقص كبير فى التعبير الجينى لجين Bax ، في حين أظهرت الجرذان الإناث زيادة كبيرة في التعبير عن الجين Hmox و نقص فى جينى Bax و Tnf. كما أظهر النشاط الكلي لمضادات الأكسدة فى الكبد انخفاض في الذكور بعكس

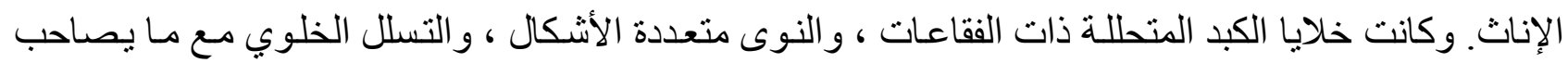

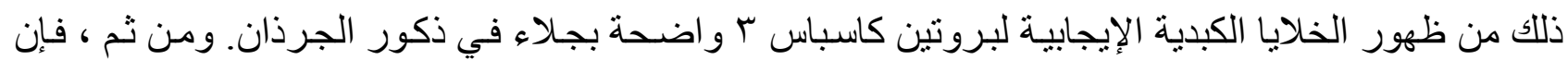

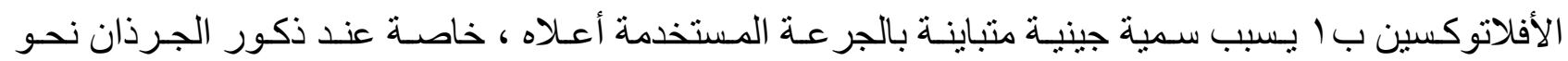

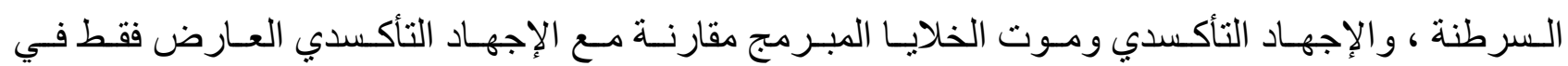

